\title{
胸部電算化衒層撮影
}

\author{
高麗大學校 醫科大學 放射線科學敉室 \\ 鄭圭唡
}

\section{CT of the Thorax}

\section{Kyoo Byung Chung}

\section{緒論}

$\mathrm{CT}$ 느캔의 개발이후 종래의 影像診斷분야에 일대 변 혁을 가져온 것은 周知의 사실이다. 二次元的인 X-선

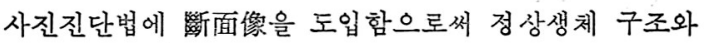
병변의 三次元的 이해에 획기적인 기여를 하게되었고 1972년 CT 스캔의 원리와 임 상응용예를 밭표한 영국 의 G.N. Hounsfield 박사가 이 공로로 1979년도 노벨 의학상을 받게 되었다.

$\mathrm{CT}$ 스캔이 頭頸部 깇 腹部질한의 진단에 크게 기여 하고 있음은 다 아는 사실이나 최근 기계적인 발달과 아울러 많은 임 상적 연구의 결과로 $\mathrm{CT}$ 스캔이 胸部질 환의 진단과 치료에도. 중요한 위치를 차지하게 되었다.

\section{檢 查 方 法}

$\mathrm{CT}$ 스캔이 横斷像이라는 점은 다른 부위 즉 두부 또 는 복부의 경우와 마찬가지이나 훙부는 心藏搏動 및 呼吸運動등의 계속 반복되는 불가피한 운동배문에 $\mathrm{CT}$ 스캔검사에 상당한 제한이 따른다.

첫째, 기계의 크기가 두부用보다는 커서 전신이 기 계속으로 들어갈 수 있어야 하고 둘째, 스캔시간이 두 부用보다는 짧아야 한다. 스캔시간은 이.론적으로는 짧 을수록 좋다고 할 수 있으나 5 초이내면 만족할 수 있 다. 세째로 조영제는 終隔洞질환 또는 肺의 血管性질 환이 의심될 해는 다량정맥주사가 필수적이고 식도질 환이 아닌 경우는 흔히 經口造影劑는 쓰지 않는다. 네 째, 切片의 두께는 찾고자하는 병변의 크기와 유관하 나 $5 \mathrm{~mm}$ 내지 $1 \mathrm{~cm}$ 정도의 두께면 대부분의 경우 불

본 논문은 대한결핵 학회 1984년 1월 월례집담회에서 발표된 특강의 초록입니다.
편함이 없고 coronal 또는 saggital 영 상재생이 필요한 경우가 많으므로 切片사이를 띄우지 않고 연속 스캔하 는 것이 바람직하다. 검사범위는 흔히 肺尖상단에서 양쪽 副腎부위까지를 포함하나 필요에 따라 상하로 약 간씩 연장검사하기도 한다.

\section{胸部撗斷解剖學}

훙부에는 각종 중요장기가 차지하고 있고 더우기 휭 단면의 관찰은 종래의 검사방법으로는 알기 어려웠으 므로 정상구조의 이해가 先行되어야만 병변진단이 가 능할 것이다. 우선 종격 동구조, 즉 심장, 대혈관과 그 分枝, 식도, 기관 및 임파절둥이 구별되어야 한다. 다 량의 조영제를 주입한 후에 행한 스캔에서는 혈관과 타장기조직과의 구별은 용이하다. 眠門의 폐동맥, 폐 정맥, 임파절 및 기관지의 크기 모양 및 상호관계를 분석관찰하여야 하고 폐실질의 각부위 관찰이 필요할 것이다. 늑막은 정상인에서 $\mathrm{CT}$ 느캔상 잘 보이지 않으 나 병변이 있으면 볼 수 있고 훙곽, 액와 및 횡경막둥 의 횡 단면에 익숙해야만 병변진단이 가능하다. 특히 우측 횡격막아래의 肝上部가 횡단되어 폐실질내의 원 형병변과 비숫하게 보이는 경우가 흔한데 익숙하지 못 한 사람은 주의를 요한다.

\section{胸部疾患의 CT 所見}

\section{1. 肺疾患}

가장 흔히 훙부 $\mathrm{CT}$ 느캔을 하게되는 예 는 혹부종괴, 그 중에서도 폐암의 경우가 가장 많을 것이다. 상당한 크기의 폐종괴는 보통 흉부 X-선사진에서도 그 크기, 모양 및 위치가 결정되지만 $\mathrm{CT}^{\mathrm{T}}$ 스캔에서는 보다 정확 하게 3 차원적인 구조와 크기 및 위치를 알 수 있어 많 


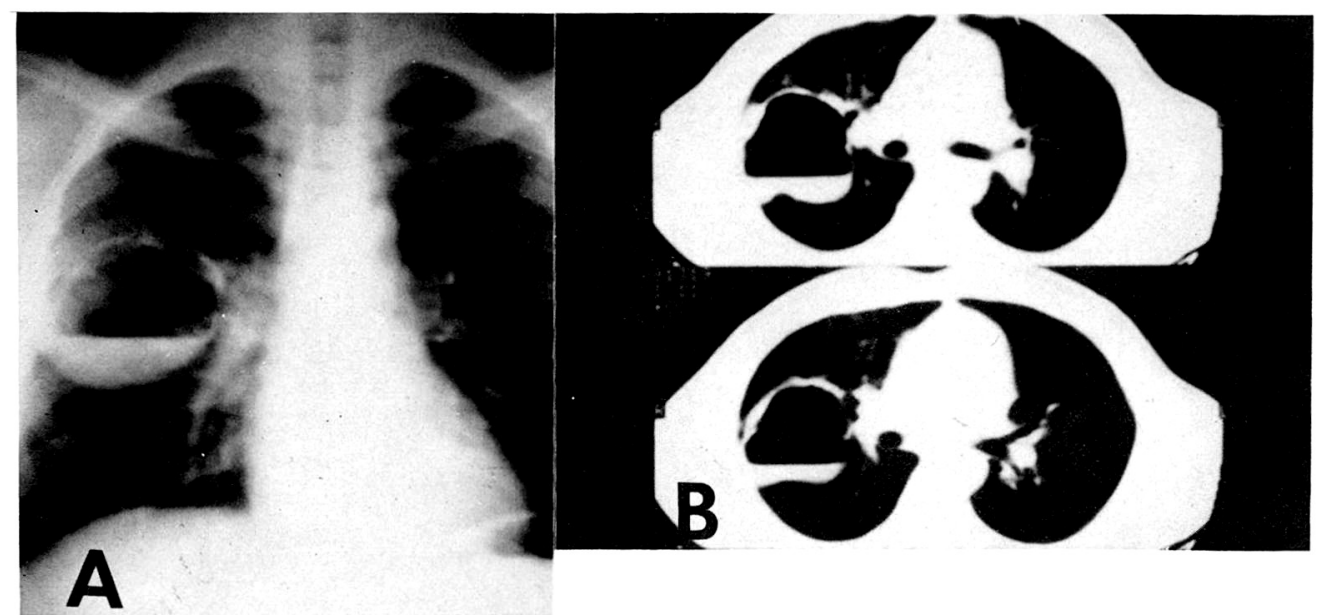

Fig. 2. Lung abscess. A: Chest PA. B: CT scan. Entire outline of the abscess cavity is well visualized.

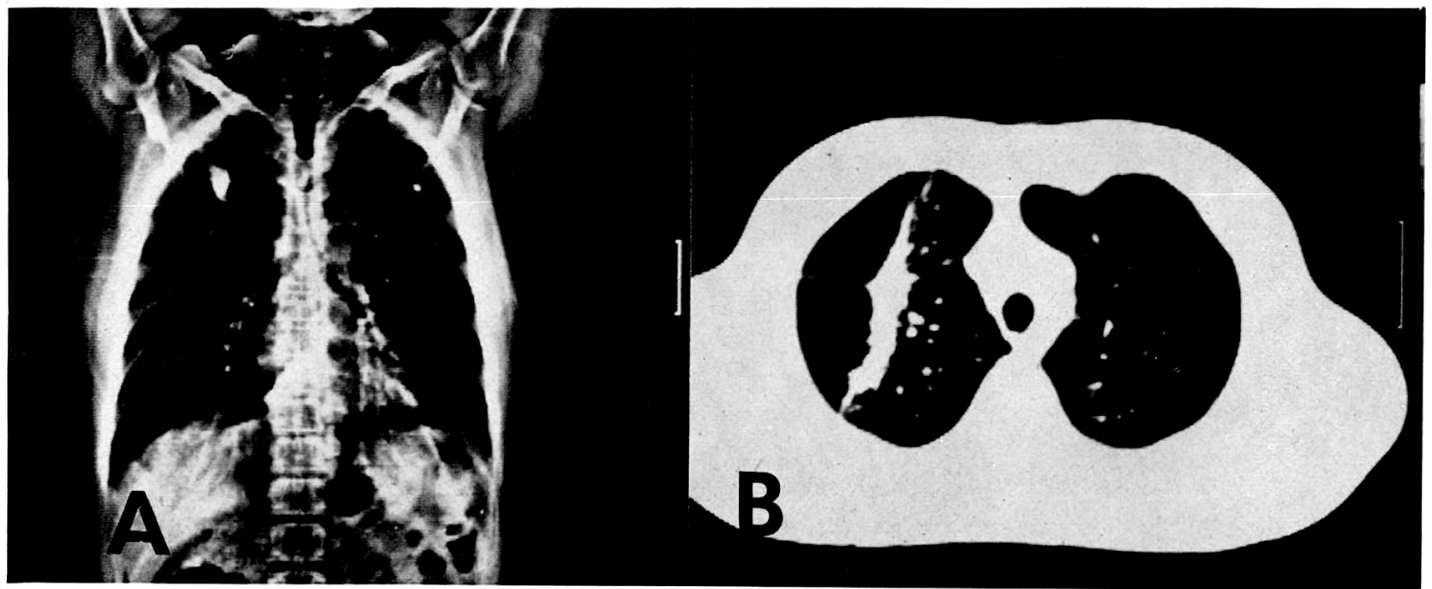

Fig. 3. Tuberculous granuloma. A: CT scout view of chest. B: CT scan. Irregular, spindle shaped lesion is seen in right apex. There is no calcium component in the lesion, so the neoplastic lesion is more likely then granuloma.
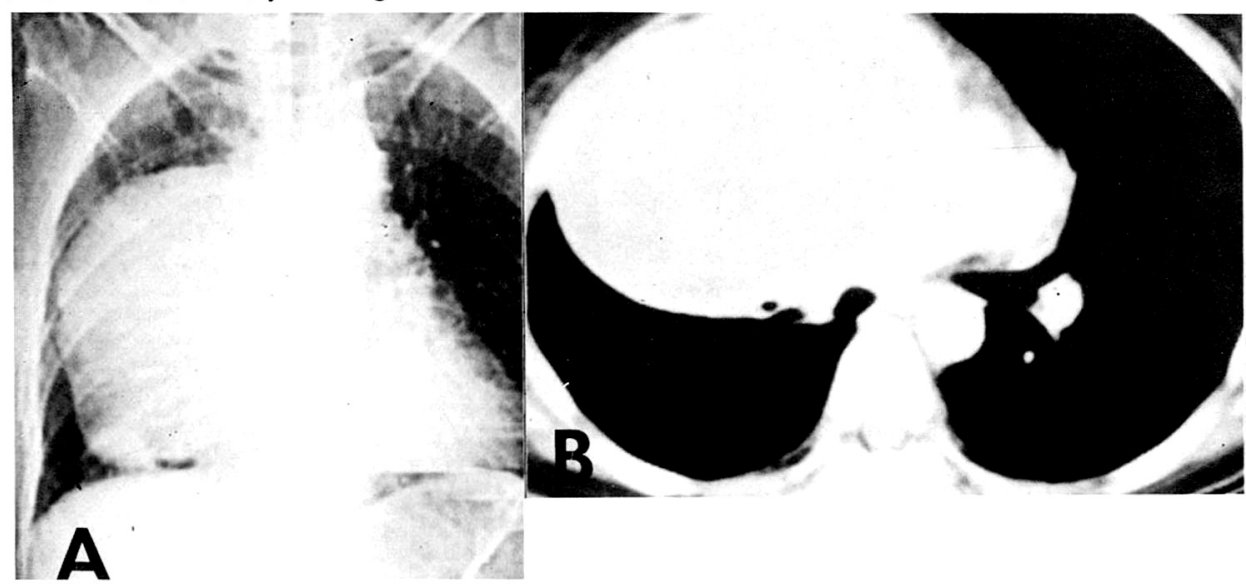

Fig. 4. Male, 14 yearsrold. Mediastinal germ cell tumor. A: CT scout view. B: CT scan. Homogenous, well capsulated mediastinal tumor is seperated from other mediastinal structures. 
Table 1. TNM Classification of the Lung Cancer

\section{$\mathrm{T}:$ Primary tumor}

TO No evidence of primary tumor

TX No gross visualization of tumor

T 1 Lesser than $3 \mathrm{~cm}$, no invasion proximal to a lobar bronchus

T 2 More than $3 \mathrm{~cm}$, invades visceral pleura, atelectasis

T 3 Invading chest wall, diaphragm, mediastinum, carina within $2 \mathrm{~cm}$, pleural effusion

$\mathrm{N}$ : Regional Lymphnodes

No No node metastasis

N 1 Peribronchial and/or ipsilateral hilar

N 2 Mediastinal node

$\mathrm{M}:$ Metastasis

Mo No distant metastasis

M 1 Distant metastasis

Table 2. CT Findings of Lung Abscess vs Empyema 70 Lesions in 63 Patients(From DD Stark, 1983)

\begin{tabular}{lcc}
\hline CT Findings & $\begin{array}{c}\text { Lung abscess } \\
(\%)\end{array}$ & $\begin{array}{c}\text { Empyema } \\
(\%)\end{array}$ \\
\hline Wall characteristics & 88 & 6 \\
Thick & 12 & 94 \\
Thin & 0 & 93 \\
Width uniformity & 14 & 91 \\
Smooth margin & 17 & 91 \\
Smooth exterior & 0 & 68 \\
Pleural seperation & & \\
("split pleura") & 0 & 47 \\
Lung compression & & \\
Chest wall angle & 83 & 14 \\
$\quad$ Acute & 0 & 70 \\
$\quad$ Obtuse & & \\
Shape & 67 & 11 \\
$\quad$ Round & 0 & 63 \\
Lenticular & & \\
\hline
\end{tabular}

은 도움을 준다. 또 그 크기가 보통 사진에서는 보기 어려운 작은 원발성 또는 전이성병변도 $\mathrm{CT}$ 에서는 인 지가능하고 기관지나 늑막과의 관계 및 무기폐의 정도 를 알 수 있으며 폐문이나 종격동으로의 전이 유무도 알 수 있는 장점이 있어 폐암의 病期결정에 도움을 준

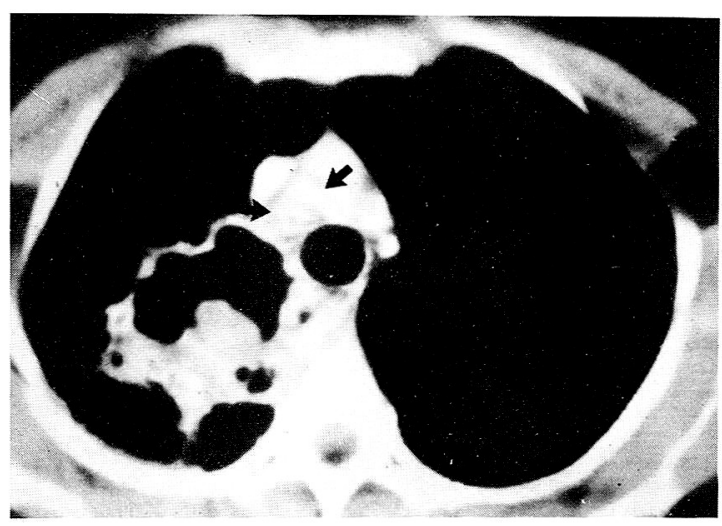

Fig. 1. Lung cancer, adenpcarcinoma, right upper lung. A large tumor mass with necrotic changes are well demonstrated. And mediastinal involvement is also seen(arrows).

다(Table 1)(Fig. 1). 폐문 또는 종격동으로의 전이유 무에 대한 $\mathrm{CT}$ 진단의 정확성에 관해서는 相異한 문헌 보고가 많은 것이 사실이나 일반적으로 임파절의 크기 가 $1.5 \mathrm{~cm}$ 를 초과하면 병변이 있는 것으로 간주하고 있다. 임파절존재위치에 따라 크기의 上限에 차이를 주 자는 주장도 있으나 어쨌든 상한크기를 높게 잡으면 false negative 가 많고 반대로 낮게 정하면 false positive 가 많은 것은 쉽게 이해할 수 있을 것이다.

종양뿐만 아니라 염 증성병변의 예에서도 스캔이 진 단에 도움을 주는 것은 당연하다(Fig. 2). 폐농양은 단순 $\mathrm{X}$-선사진에서도 쉽게 진단될 경우가 많으나 그 정확한 위치 및 크기를 아는데는 $\mathrm{CT}$ 스캔이 큰 역할을 하며 가끔 훙막내에 생긴 膿胸과 구별이 어려운 때가 있으나 CT 스캔을 행하면 대개 구별가능하다(Table 2). 염증성 육아종 (granuloma) 과 新生物과의 감별에 도움 이 되는 칼슘침착여부는 보통 X-선사진보다 $\mathrm{CT}$ 스캔 에서 훨씬 정확하게 확인할 수 있으나 칼슘이 침착되 지 않은 염증성병변은 그 모양만으로 신생물과 구별이 어려운 경우도 있다(Fig. 3). 그 외 기관지확장증, 국 소폐기종 및 방사선 폐염등의 진단에도. $\mathrm{CT}$ 스캔이 도 움을 줄 수 있다.

\section{2. 終隔洞病變}

종격동의 흔한 병변인 각종 종괴의 감별진단에 $\mathrm{CT}$ 스캔이 기여함은 물론이다. 크기와 위치뿐만아니라 피 막의 모양, 칼슘함유여부, 내용물의 밀도등을 관찰함으 로써 종격동 종괴 감별진단에 결 정적 역할을 할 수 있 어 畸形腫, 脂肪腫 및 胸腺腫등은 상호 감별이 용이하 
다(Fig. 4). 홍곽내甲狀腺은 그 특징적인 고밀도 패때 둔에 쉅게 진단 가능하다. 조영제 주입전, 칼슘침착이 아니면서 연부조직의 민도가 $100 \mathrm{CT}$ 단위 이상인 것은 정 상조직으로는 沃度함량이 특이하게 많은 갑상선조직 뿐이다. 심장 또는 종격동의 대소 혈관과 관계되는 병 변을 타종격동종기와 구별가능하여 혈관조영찰영, 또 는 針生檢등의 침습적검사를 파할 수 있다. 반대로 침 생검을 시도할 때에는 훌륭한 길잡이가 될 것이다.

\section{3. 助膜 吕 胸壁病變}

정상 늑막강은 $\mathrm{CT}$ 스캔에 보이지 않는 것이 常例이 나 4겹의 늑막으로 이루어진 fissure 들은 흔히 관찰된 다. 늑막강내에 삼출액이 고여 있으먼 보통 $\mathrm{CT}$ 스캔 에서 잘 보이는데 확실한 데이터는 없지만 경험상 소 량의 늑막삼출액을 찾아내는데는 가장 민감한 검사가 $\mathrm{CT}$ 스캔이라고 믿어진다. 전술한 바와같이 膿胸은 肺 膿瘍과 구별이 가능하고 늑막석회침착이 췹게 인지되 는 것은 말할 것도 없다. 늑골 또는 훙벽에 병변이 있 을 때에도 제한된 예이지만 스캔이 도움을 줄 수 있고 腋窩임파절종대는 쉽게 발견되며 乳癌의 진단에도 이 용할려는 시도도 있어 왔다.

\section{結諭}

$\mathrm{CT}$ 느캔이 훙부 질환의 감별진단 및 치료에 큰 도움 을 줄 수 있다고 믿는다. 물론 종래의 훙부X-선검사를
$\mathrm{CT}$ 스캔이 대체할 수 있을 것으로 생각지는 않지만 또 단순 X-선검사가 값싸고 간단하면서 많은 임상정보를 제공해 준다는데는 전적으로 동감이지만 선택된 훙부 질환 즉 폐종양 또는 종격동종양의 경우에 는 $\mathrm{CT}$ 스캔 이 더 많은 정보를 제공해 주므로 임 상활용이 더욱 활 발해지리라고 생각된다. 더 짧은 스캔시간, 더 높은 解像力 그리고 더 작은 검사비용등의 조건을 충족시켜 준다면 $\mathrm{CT}$ 느캔의 훙부질환 이용은 한층 높아질 것 이다.

\section{REFERENCES}

1) Joseph KT Lee, Stuart S Sagel and Robert J Stanley: Computed Body Tomography. pp. 55129, Raven Press, New York, 1983.

2) Albert A Moss, Gordon Gamsu, and Harry K Genant: Computed Tomography of the Body. pp. 145-425. Saunders, Philadelphia, 1983.

3) Louis Jeanmart, Albert L Baert and Auguste Wackenheim: Computer Tomography of Neck, Chest, Spine and Limbs, pp.20-120. SpringerVerlag, Berlin and New York, 1983.

4) John R Haaga Ralph J Alfid: Computed Tomography of the Whole body. pp.430-574. Mosby, ST. Louis and Toronto, 1983.

5) E Robert Heitzman: The Mediastinum. Mosby, St. Louis, 1977. 